\title{
Covid-19 has only Temporarily Interrupted Social and Health Services in rural Albania in $\mathbf{2 0 2 0}$
}

\author{
M. Palockova (Monika Palockova)1', S. Chovancova (Stanislava Chovancova)², \\ D. Sugarova (Daniela Sugarova)², E. Zdilova (Eva Zdilova) ${ }^{2}$, F. Sasvary (Ferdinand \\ Sasvary)2, M. Sasvary (Maria Sasvary)2, D. Barkasi (Daniela Barkasi) $)^{3}$, M. Gulasova \\ (Monika Gulasova) $^{3}$, I. Kmit (lgor Kmit)3 ${ }^{3}$, M. Olah (Michal Olah)3) R. Hochman (Rastislav \\ Hochman) ${ }^{3}$, E. Haluskova (Eva Haluskova) ${ }^{3}$, M. Partelova (Martina Partelova)², \\ E. Trichard (Emanuel Trichard) $)^{4}$
}

${ }^{1}$ St. Francis School Sisters, Fier, Republic of Albania.

${ }^{2}$ St. Elizabeth University Migrant \& Refugee Program, PhD program Balkan Branch Fier Albania.

${ }^{3}$ Dept. of Tropical Diseases, Slovak Medical University Bratislava, Slovakia.

${ }^{4}$ Integrated Group of Applied Public Health IGAP Vienna, Austria.

${ }^{5}$ PRIGO University, V. Nezvala 801/1, 73601 Havirov, Czech Republic.

\section{E-mail address:}

palockova@yahoo.fr

\section{Reprint address:}

Monika Palockova

St. Francis School Sisters

Fier

Republic of Albania

Source: Clinical Social Work and Health Intervention

Pages: $17-19$

Volume: 12

Issue: 1

\section{Reviewers:}

Pedro Allegria

Mozambique

Victor Namulanda

Nairobi

\section{Keywords:}

Outpatient. Health Services. Covid-19.

\section{Publisher:}

International Society of Applied Preventive Medicine i-gap

CSWHI 2021; 12(1): 17 - 19; DOI: 10.22359/cswhi_12_1_03 CC Clinical Social Work and Health Intervention

\section{Abstract:}

During the first and second wave of Covid-19 pandemics, Balkan countries were among the least affected areas of Europe, especially those having islands as naturally protected quarantine environment (Greece, Croatia, Cyprus, Malta), as well as countries with less tourism in Spring such as Montene- 
gro, Albania, and Bulgaria. Therefore, the health care system was not overwhelmed by Covid-19 infected patients and was able to continue on normal outpatient and inpatient bases. This pilot population-based study in rural Albania shows only a low and temporary break of health and social services for just 1 month during the first wave, in April 2020.

\section{Introduction}

Primary mortality of Covid-19 varies between $0.5 \%$ (SK, MT, CYP) to $13.5 \%$ (FR), however, this is only a death rate due to virus related lung disease. Secondary mortality involves the cessation or total absence of health services for diagnosis other than Covid-19, as it was seen in Northern Italy in March and April 2020, and tertiary mortality is due to the collapse of the economy and therefore insufficient funding of health national programs such as those aimed at cardiovascular diseases or cancer.

This population-based survey presents an example of one of less affected Mediterranean Balkan countries during the first wave, where primary mortality was minimal, and secondary only indirect since the interruption of health services was experienced for one month only.

\section{Setting Methods}

The City of Fier is located in southern central Albania in an area with lower income, and limited access to hospital healthcare and previously no free of charge outpatient service. The Franciscan School Sisters from Prievoz have founded the community center also providing health and social services. In addition, they have started an outreach program aimed at households in remote villages of low economic status in order to help them with access to health care, irrespective of their socio-economic status. The project contained 4 health care workers -1 doctor and 3 nurses, and 1 social worker (French or Slovak) from January to December 2020. We have compared the number of visits during the lockdown in first wave of Covid-19 in April 2020 to other months after the quarantine measures were stopped in May 2020.

\section{Results and discussion}

Patient's flow decreased to zero in April 2020 due to the lockdown, dropping from the average of more than 110 patients per month that had vis- ited the facility in period from January to March 2020. However, it started to increase from May till September 2020. Altogether, 331 outpatient visits were recorded in 2 months, plus 121 outreaches to the rural villages starting in June.

In contrast to OPD spectrum in tropical areas, e.g. Sub-Saharan Africa, where communicable diseases of 3 major killers (HIV, TB, and malaria) are prevalent (2). In Albania non-communicable diseases are still prevalent in the adult population, including hypertension, diabetes mellitus, bronchial asthma, coronary heart disease, and in children upper respiratory tract infections followed by injuries, burns, wounds and trauma.

No confirmed cases of TB, HIV and vivax malaria were documented even during summer and touristic season. Endemic zoonoses (listeriosis, Q-fever, leishmaniasis, echinococcosis) were extremely rare. Substance abuse, including alcohol overuse, was much lower than expected.

\section{Conclusion}

Despite of Mediterranean food habits and continuous physical activity during its agricultural lifestyle, the spectrum of the commonest diseases, including civilization diseases, resulting in outpatient visits in rural southern Albania is much closer to central eastern Europe than to the sub-tropical Mediterranean Region of WHO. As the access to the health care in rural villages of Albania is limited, the outreach strategy is performed every week, similarly to what is performed in other projects in countries with limited access to funding and medications.

Preventive strategies and health policy should be focused on cessation of smoking, regular blood pressure and blood glucose measurement in adults, and on asthma and prevention of injuries in children. Vaccination policy has been maintained during the last 70 years on an acceptable level, all children seen in OPD had the basic vaccination (DTPHiB, HB, Polio plus MMR plus TB) as a result of centralized public health care 
system and universal access to education and basic health care.

\section{References}

1. KIMULI D (2020) Social and Health Programs in Sub-Saharan Africa. Med Horizon 70.2020 .6 .

2. DANCAK P 2019 Dialogue and Solidarity as a Basis for Addressing the Current Migration Crisis. In: Acta Missiologica INo. 2|Vol. 13l2019| pp. 73-83. ISSN 1337-7515.

3. WHO ANNUAL Report (2015) section Mediterranean Region, European Region, World Health Organization, Geneva - pp155-204 